\title{
Selling Points of Sewage Sludge as an Enhancing Agent of Bioremediation of Diesel Oil-Polluted
}

\section{Soil}

\section{Kingsley Tochukwu Ughamba ${ }^{1,2^{*}}$, Nnabueze Darlington Nnaji ${ }^{2}$, Kenneth Ejike Ogbonna $^{1,3}$, Chukwudi Anyanwu ${ }^{2}$}

\author{
${ }^{1}$ Department of Science Laboratory Technology, University of Nigeria, Nsukka, Nigeria \\ ${ }^{2}$ Department of Microbiology, University of Nigeria, Nsukka, Nigeria \\ ${ }^{3}$ Department of Biochemistry, University of Nigeria, Nsukka, Nigeria \\ *Corresponding author: E-mail: kingsley.ughamba@unn.edu.ng
}

\begin{abstract}
Bioremediation employing the action of microbes alone has been shown to be inadequate. The aim of this study was to evaluate the efficacy of sewage sludge (SS) in enhancing bioremediation of diesel oil-polluted soil. Diesel oil was introduced into the soil at the concentration of $10 \%(\mathrm{v} / \mathrm{w})$ and mixed with $5 \%, 10 \%$ and $15 \%(\mathrm{w} / \mathrm{w})$ of sewage sludge. The remediation of the oil was determined gravimetrically using $n$-hexane as extractant. Effectiveness of the remediation strategy was assessed by the seed germination toxicity test. At the end of forty-two days, $32.22 \%$ oil loss was recorded in the unamended polluted soil while $58.33 \%$ oil loss was recorded in the soil amended with sewage sludge. Hydrocarbon- utilizing bacteria $(H U B)$ counts were significantly higher $(P \leq 0.05)$ in the sewage sludgeamended options, ranging from $5.3 \pm 0.9 \times 10^{6}$ to $12.3 \pm 0.75 \times 10^{6} \mathrm{CFU} / \mathrm{g}$ soil, as compared to the unamended control soil which gave $1.0 \times 10^{6}-3.8 \times 10^{6} \mathrm{CFU} / \mathrm{g}$ of soil. The hydrocarbon-utilizing bacteria isolated from both the control and amended soils were identified tentatively as Bacillus cereus, Pseudomonas putida, Micrococcus varians, Corynebacterium sp, Acinetobacter sp and Bacillus licheniformis based on their cultural, morphological and biochemical characteristics. The fungal counts in the SS-amendment options were also higher than was recorded in the control option ranging from $3.8 \times 10^{5} \pm 0.2$ to $11.6 \times 10^{5} \pm 0.25$. Aerobic fungi isolated were Aspergillus niger, Aspergillus flavus, Fusarium sp, Cladosporium sp and Penicillium sp. The highest oil loss and germination indices were recorded in $S S$-amended options. There was a significant difference $(P \leq 0.05)$ in oil loss and germination index between the unamended control soil and amended soil.
\end{abstract}

Keywords - Bacteria, sewage sludge, germination, diesel oil, pollution.

\section{INTRODUCTION}

Petroleum-based products are the major energy source for vehicles, daily life and industry owing to their high energy content. Exploration, mining and transport of the same in developing countries have led to serious environmental hazards due to accidental spills [1]. The increasing use of diesel in car engines, industrial trucks and generators has led to a marked increase in the demand for diesel fuel in Nigeria and damages due to soil contamination by diesel oil may be extensive and have long term effect [2]. Release of hydrocarbons into the environment, whether accidentally or due to anthropogenic activities, is a main cause of water and soil pollution.
Diesel oil is a mixture of aromatic compounds and alkanes and is usually documented as soil pollutants because of their frequent release from accidental spills and leakage from storage tanks [3].Diesel is a medium-weight petroleum fuel with a boiling point range of $175^{\circ} \mathrm{C}$ to $355{ }^{\circ} \mathrm{C}$ [4]. It is composed of over 200 petroleum hydrocarbon compounds corresponding to the molecular weight range of $\mathrm{C}_{10}-\mathrm{C}_{28}$ alkanes [5,6]. The exhaust fumes of diesel contains up to forty air pollutants including many suspected or known carcinogenic substances such as arsenic, formaldehyde and benzene. It also contains other harmful environmental pollutants, including nitrogen oxide, currently the single most important ozone-depleting emission [7]. 
Oil exploration and exploitation are very lucrative and major revenue earner in Nigeria. However, like most industrial activities, it produces environmental hazards that are "slow poisons" in that they often take months and years to cause disease and death. The slow and obvious environmental hazards occasioned by exploration of oil and exploitation of the same make it difficult to fully understand their impart in the health of Nigeria as a people, especially in the oil-bearing communities, even with the emergence of non-communicable diseases as major causes of ill health in Nigeria.

The need for remediating diesel oil-polluted areas has induced development of new technologies to detoxify contaminants not only through chemical or physical methods which are expensive, but through biological techniques as well. Bioremediation is an eco-friendly and cost-effective option that removes contaminants or renders them innocuous using natural biological activity. Microorganisms degrade these compounds by using enzymes in their systems and can be useful in cleaning up contaminated sites [8]. However, bioremediation employing the action of microbes alone has proven rather inadequate. Lack of essential nutrients such as nitrogen has been identified as a major limiting factor in petroleum hydrocarbon degradation among various factors. Therefore, the addition of organic or inorganic nutrients rich in nitrogen content remains an effective approach to enhance bioremediation process [9]. The use of organic wastes to stimulate the indigenous hydrocarbon degraders have been widely demonstrated $[10,11,12]$. However, few works have been done on the use of sewage sludge in enhancing the bioremediation of diesel oil-impacted soils. The present study was therefore undertaken to assess the enhancement potential of sewage sludge for diesel oil bioremediation in soil.

\section{MATERIALS AND METHODS}

\section{Collection and Processing of Samples}

Soil sample used in this study was collected from an agricultural farm land from different sites in Obukpa, Nsukka, Southeast, Nigeria at a depth of $0-30 \mathrm{~cm}$. The soil sample was air-dried for 48 hours and sieved through a 2-mm mesh. Sewage sludge was collected from the University of Nigeria Sewage Treatment Plant while diesel oil was purchased from TOTAL filling station in Nsukka metropolis. Bean seeds (Phaseolus vulgaris) were obtained from the Department of Crop Science, University of Nigeria, Nsukka.

\section{Physicochemical Analyses Soil and Sewage Sludge}

Physicochemical properties of soil and sewage sludge such as particle size distribution, percentage moisture content, $\mathrm{pH}$, total organic carbon (\%TOC), \% nitrogen content and total phosphorus were analysed following standard protocol [13].Triplicate determinations were made for each assay.

Determination of Extraction Efficiency of Different Solvents for Diesel Oil

Three different organic solvents namely n-hexane, dichloromethane and diethylether were used to extract diesel oil and their extraction rates were determined. The best solvent in terms of extraction efficiency for diesel oil was later used for the bioremediation assay. The extraction efficiency was determined gravimetrically. Briefly, forty grammes of the soil sample was transferred into a $250 \mathrm{~mL}$ flask and polluted with $4 \mathrm{~mL}$ of diesel oil. A $4 \mathrm{~mL}$ quantity of diesel oil was used so as to simulate a $10 \%$ pollution condition that would be studied in the present work. A $100 \mathrm{~mL}$ quantity of the three organic solvents was added separately to each polluted soil sample setup and the set-ups shaken for six hours at $180 \mathrm{rpm}$. The solution was then filtered using a Whatman No 4 filter paper and the weight of the extracted oil recorded. The extraction efficiency of the organic solvents for diesel was then determined by weight difference following the formula of [14]. The experiment was carried out in triplicates.

Extraction efficiency
$=\frac{\text { Weight of } 4 \mathrm{~mL} \text { diesel oil }- \text { Weight of oil extracted from soil } \mathrm{x} 100}{\text { Weight of } 4 \mathrm{~mL} \text { diesel oil }}$

\section{Soil Preparation for Bioremediation Study}

A $1 \mathrm{~kg}$ quantity of the sieved soil was placed in sterile polythene bags and $10 \%(\mathrm{v} / \mathrm{w})$ of diesel oil was added, mixed thoroughly, and left undisturbed for 48 hours. After two days, $5 \%, 10 \%$ and $15 \%(\mathrm{w} / \mathrm{w})$ pulverized sewage sludge were respectively introduced into the diesel oil-polluted soils and mixed thoroughly. Soil sample contaminated with $10 \%$ (v/w) diesel oil without sewage sludge amendment served as control. The moisture content of the soil was adjusted to $60 \%$ water holding capacity by the addition $50 \mathrm{~mL}$ of sterile distilled water (three times weekly) and the set-up kept at room temperature $\left(28 \pm 2^{\circ} \mathrm{C}\right)$. The experiment was set up in triplicates.

\section{Determination of Diesel Oil Removal from Soil}

Periodic sampling from each polythene bag was carried out every seven days in order to determine the residual diesel oil and enumerate heterotrophic microbes. Gravimetric and spectrophotometric methods of [10] with slight modification was employed in the determination of residual diesel oil present in both the control soil and amended options. Composite soil samples weighing five grammes were put in 
$50 \mathrm{~mL}$ flasks and $10 \mathrm{~mL}$ of $\mathrm{n}$-hexane was added. N-hexane was used because it extracted the highest amount of oil in the extraction efficiency experiment (see result section). The setups were shaken with a rotary shaker at $180 \mathrm{rpm}$ for 10 hours to allow for an efficient and complete oil extraction with $\mathrm{n}$ hexane. The mixture was then filtered with a whatman No 4 filter paper. The filtration was done repeatedly two times to ensure complete extraction of the liquid phase. The filtrate was diluted by adding $50 \mathrm{~mL}$ of $\mathrm{n}$-hexane to $1 \mathrm{~mL}$ of the extracted diesel oil and the absorbance of the solution measured at 460 nm (Shimadzu UV 1800) using n-hexane as blank. The total petroleum hydrocarbon (TPH) was estimated by extrapolating from a standard curve derived from different concentrations of fresh diesel oil diluted with $\mathrm{n}$-hexane. Percent remediation (R) was calculated using the following formula:

$$
\mathrm{R}=\frac{T P H i-T P H r}{T P H} \times 100
$$

Where TPHr and TPHi are residual and initial TPH concentrations

\section{Enumeration and Identification of Oil-utilizing Bacteria and Fungi}

Ten-fold serial dilutions of soil samples from each option was made by suspending $10 \mathrm{~g}$ of soil in $90 \mathrm{~mL}$ of distilled water and shaken vigorously for proper mixing. The suspension was serially diluted up to $10^{-8}$. A $0.1 \mathrm{~mL}$ aliquot of $10^{-5}, 10^{-6}$ and $10^{-}$ 7 dilutions was separately inoculated in sterile nutrient agar plates by the standard spread plate method [15] for active aerobic heterotrophic bacteria isolation. The nutrient agar medium was supplemented with $50 \mu \mathrm{g} / \mathrm{mL}$ nystatin to suppress the growth of fungi. The agar plates were incubated at $37^{\circ} \mathrm{C}$ for $24 \mathrm{~h}$ after which colony forming units per gram of soil samples were calculated. Three replicate samples from each oil-polluted soil were withdrawn every 7 days for the enumeration of total aerobic heterotrophic bacteria (AHB).

Hydrocarbon utilizing bacteria (HUB) in the soil samples were enumerated on Bushnell Has agar using the vapour phase transfer method as described by [16]: A filter paper saturated with sterile diesel oil was aseptically placed on the inside of the cover of inverted inoculated petri dishes and incubated at $28^{\circ} \mathrm{C}$ for 7 days. Morphologically different colonies of hydrocarbon-utilizing bacteria were picked and pure isolates obtained by repeated sub-culturing on nutrient agar. The bacterial isolates were characterized and tentatively identified using microscopic techniques and biochemical tests such as catalase, urease, oxidase, starch hydrolysis, spore forming, $\mathrm{H}_{2} \mathrm{~S}$ production, motility, citrate utilization and methyl-red.
For the enumeration and isolation of fungi, $0.1 \mathrm{~mL}$ of the appropriate dilution of each of the set-ups was inoculated into Sabouraud Dextrose Agar (SDA) plates and incubated at $28 \pm 2^{\circ} \mathrm{C}$ for 4 days. Colony counts were taken and pure isolates obtained by repeated sub-culturing on SDA plates. The fungal isolates were characterized by slide culture and microscopic techniques and identified by the schemes of [17].

\section{Seed Germination Toxicity Test}

Toxicity of the soil to seed germination after a 42-day bioremediation experiment was assessed following the seed germination test of [18]. Seeds of Phaseolus vulgaris (common bean) were used in this study owing to their sensitivity to hydrocarbon in soil. For each soil preparation, 40 $\mathrm{g}$ of thoroughly-mixed remediated soil samples from both the control soils and the amended soil was placed in $100 \times 15 \mathrm{~mm}$ petri-dish. Six viable bean seeds were placed evenly throughout each petridish and covered with $10 \mathrm{~g}$ of dry sand. The moisture content of the set-ups were maintained at $60 \%$ water holding capacity. Triplicate determinations was made for each assay. At the end of 10 days, the number of seeds that germinated from the surface of the soil was counted and root length measured to the nearest centimeter using a metre rule. The results were evaluated using the formula of [19] with slight modification. Soil neither polluted nor amended served as the positive control soil while polluted soil without amendment served as negative control.

- Germination index $(\%)=(\mathrm{SG} \times \mathrm{LR}) / 100$

- $\mathrm{SG}=(\mathrm{ET} / \mathrm{CG}) \times 100$

- $\mathrm{LR}=(\mathrm{LRT} / \mathrm{LRC}) \times 100$

Where $\mathrm{SG}=$ number of seed germination, $\mathrm{LR}=$ root length (elongation), ET=number of seeds that germinated on treated soil, $\mathrm{CG}=$ number of seeds that germinated on positive control soil, LRT= root length on treated soil, $\mathrm{LRC}=$ root length on positive control soil.

\section{Statistical Analysis of Data}

The data obtained in the present study were subjected to oneway analysis of variance (ANOVA). Relationship between variables and comparison of means of the different treatments were tested for level of significances at $\mathrm{P} \leq 0.05$ using least square difference and post-hoc multiple comparison tests. The data analysis was performed using SPSS.

\section{RESULTS}

Physicochemical Properties of Soil and Sewage Sludge

The physicochemical properties of the soil and SS used in this study are presented in Table 1. The \% organic nitrogen 
content of the soil was 0.02 and available phosphorus content of $10.64 \%$. Other parameters of the soil in percentage are: TOC 2.49, moisture 15.38 and the $\mathrm{pH}$ is 4.9 . The sewage sludge had $\mathrm{pH}$, nitrogen content, TOC and total phosphorus content of $3.4 \pm 0.015, \quad 0.28 \pm 0.03, \quad 11.97 \pm 0.07$ and $17.92 \pm 0.034$, respectively and nitrogen content of 0.28 and TOC of 11.97. Pig droppings had nitrogen content of 0.238 while poultry manure had organic nitrogen content of 0.098 and TOC of 56.86
Table 1. Physicochemical Properties of Soil and Sewage

\begin{tabular}{lll}
\multicolumn{3}{c}{ Sludge } \\
\hline Parameter & $\begin{array}{l}\text { Non-polluted } \\
\text { Soil }\end{array}$ & Sewage sludge \\
& $4.90 \pm 0.37$ & $3.40 \pm 0.015$ \\
$\mathrm{pH}$ & $0.042 \pm 0.02$ & $0.28 \pm 0.030$ \\
Nitrogen & $2.49 \pm 0.45$ & $11.97 \pm 0.07$ \\
Organic carbon & $10.64 \pm 0.50$ & $17.92 \pm 0.034$ \\
Phosphorus & & \\
(PPM) & $10.38 \pm 0.30$ & $8.69 \pm 0.229$ \\
Moisture(\%) & $71.00 \pm 0.41$ & - \\
Clay (\%) & $19.50 \pm 0.06$ & - \\
Silt (\%) & $9.50 \pm 0.08$ & - \\
Sand (\%) & Clayey Loam & \\
Texture & & \\
\hline
\end{tabular}

Extraction Efficiency of Solvents for Diesel Oil

The amount of diesel oil (in percentage) that was extracted by three different solvents namely: n-hexane, dichloromethane and diethylether six hours after polluting soil with $10 \%$ (v/w) diesel oil were $80.72 \%, 80.68 \%, 80.56 \%$.

\section{Bioremediation of diesel oil in soil}

The levels of bioremediation of diesel oil in the unamended control soil and soil amended with 5\% SSare shown in Figure1. Percentage oil loss in the sewage sludge-amended option ranged between $27.78 \pm 1.27$ and $58.33 \pm 0.67$. In the unamended control soil, the percentage loss ranged between $19.93 \pm 0.96$ and $32.22 \pm 0.17$

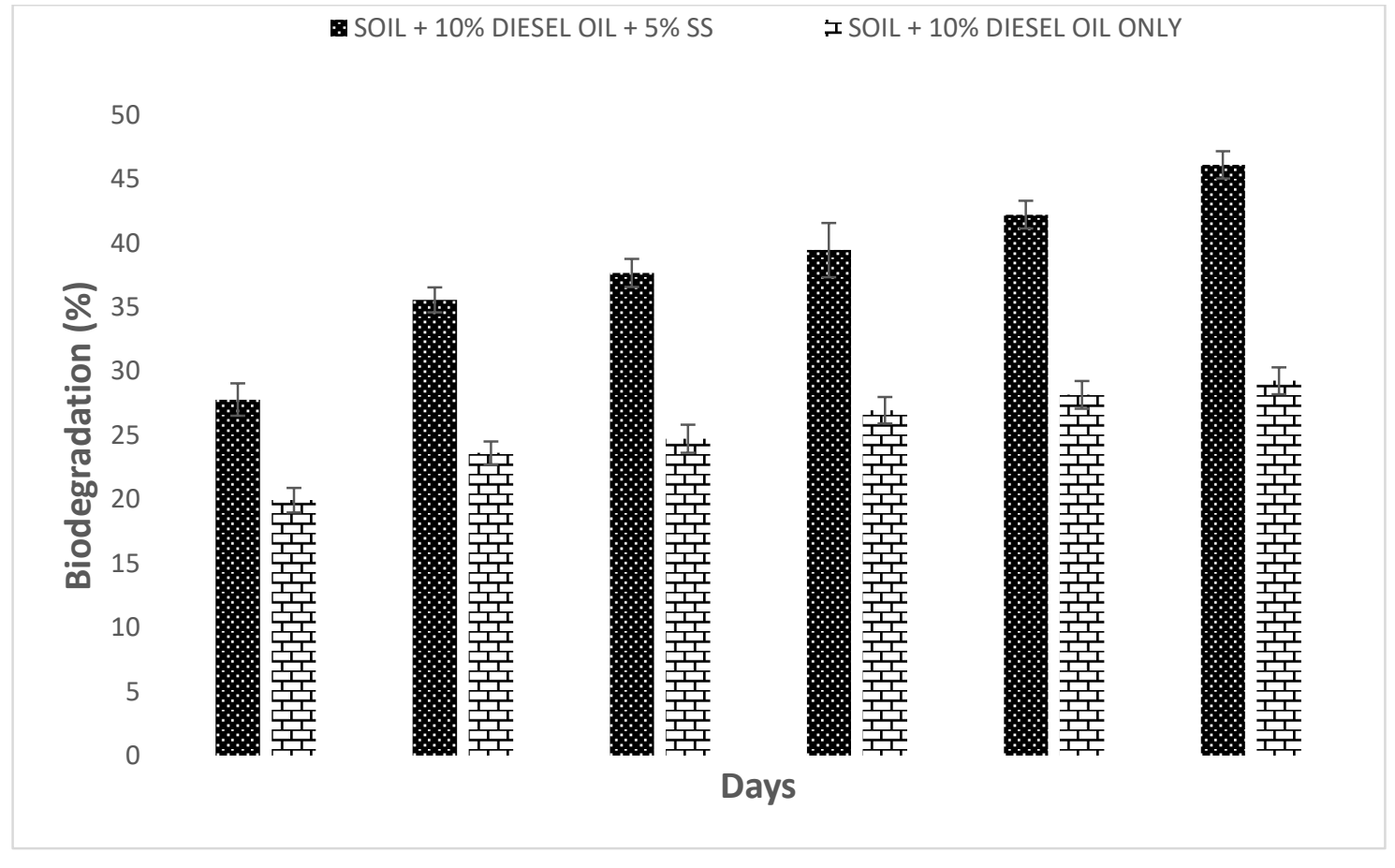


Fig.1: Bioremediation of diesel oil in polluted soil amended with $5 \%$ SS

Figure 2 shows the level of oil loss in control soil and polluted soil amended with 10\% SS over a 42-day period. Percentage oil loss in the SS-amended option ranged from $35.94 \pm 0.98$ to $48.75 \pm 1.27$

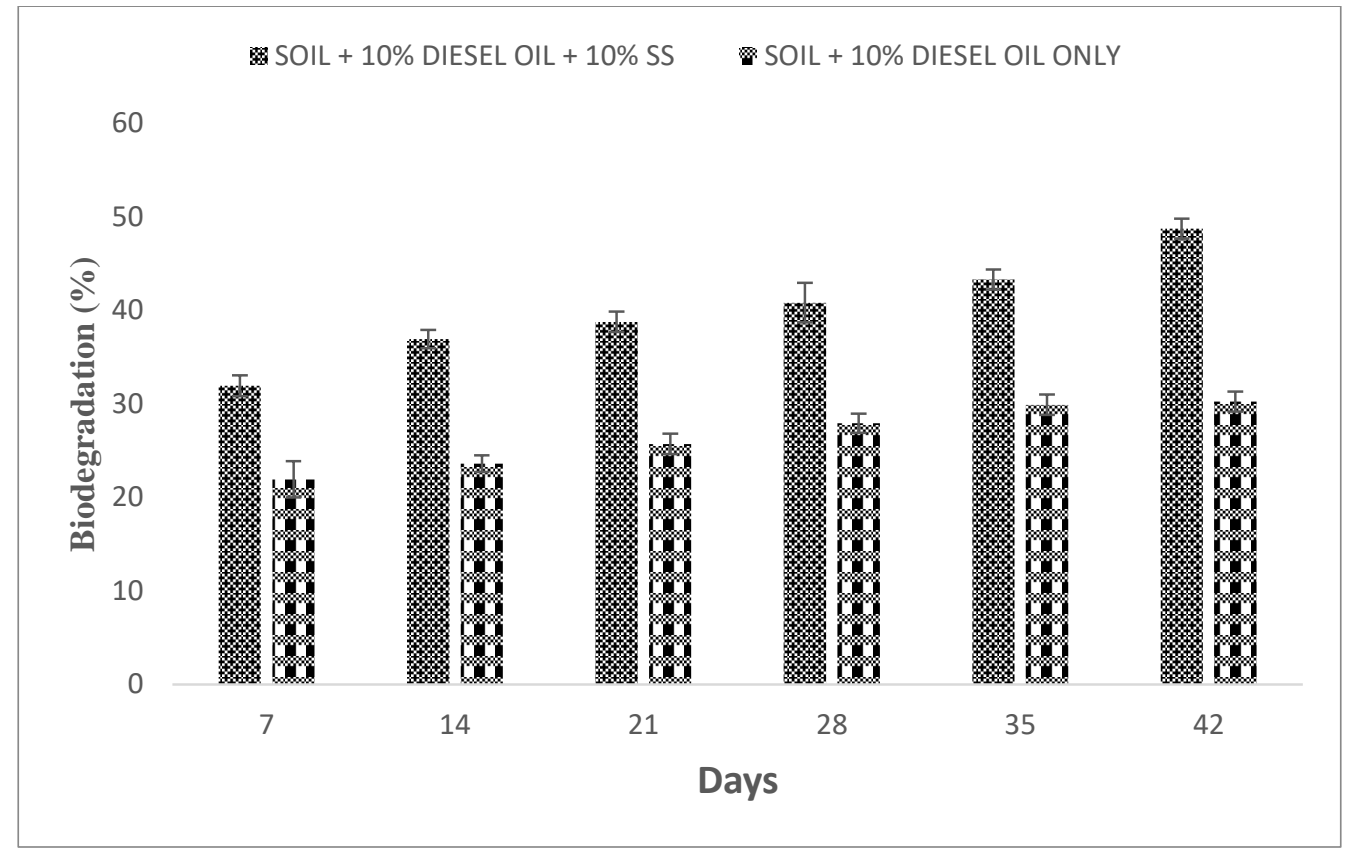

Fig.2: Bioremediation of diesel oil in polluted soil amended with 10\% SS

The level of oil loss in the control soil and polluted soil amended with 15\% SS over a 42-day period is presented in Figure 3. Percentage oil loss in the SS-amended option ranged from $36.61 \pm 1.09$ to $58.33 \pm 2.12$

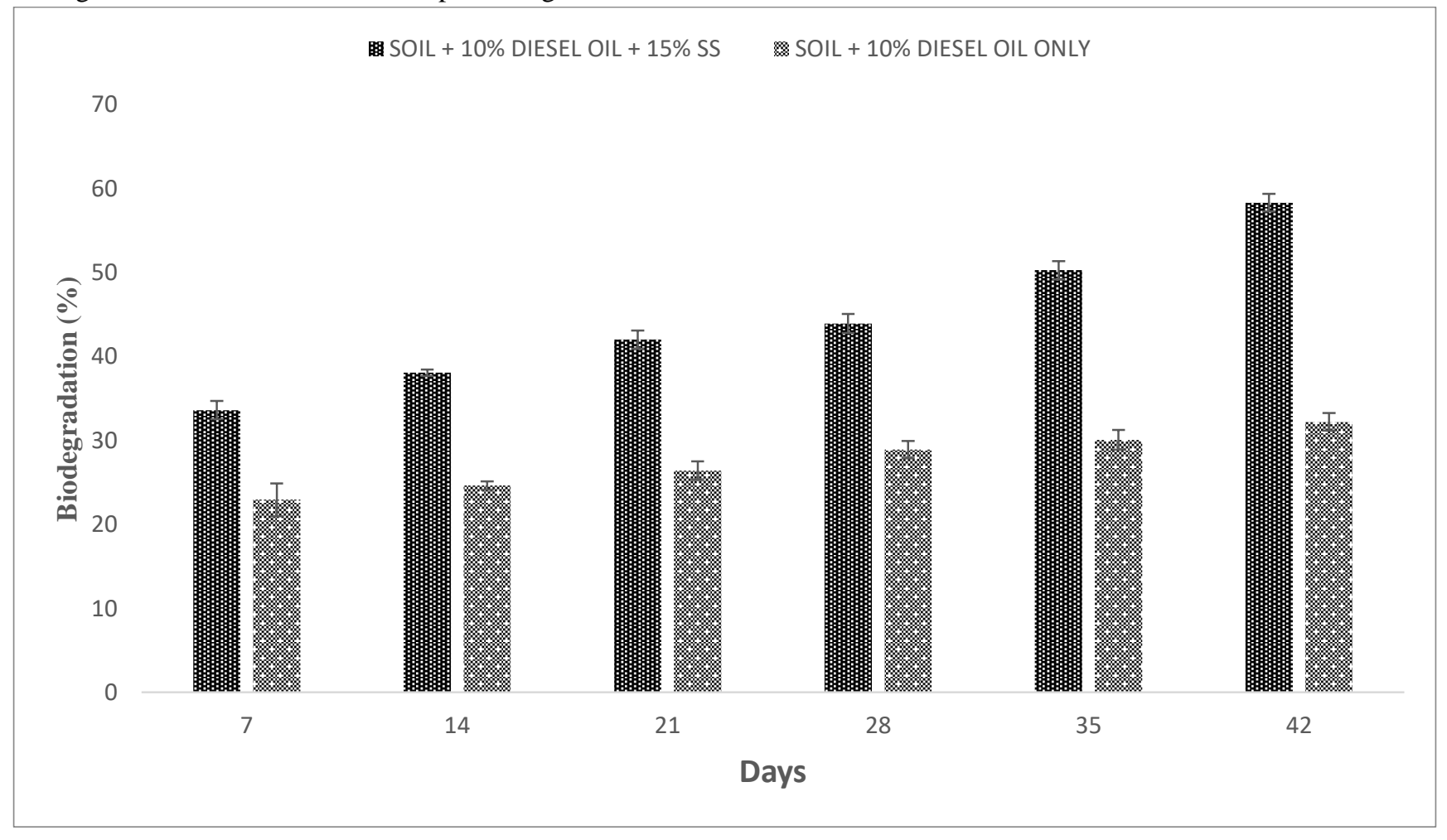


Fig.3: Bioremediation of diesel oil in polluted soil amended with $15 \%$ SS

\section{Active Aerobic Heterotrophic Bacterial (AHB) Counts}

The total heterotrophic bacteria in control soil and polluted soil amended with 5\% SS are presented in Figure 4. AHB counts in the SS-amended option ranged from $8.3 \times 10^{7} \pm 2.78$ to $22.5 \times 10^{7} \pm 0.71 \mathrm{CFU} / \mathrm{g}$. Control soil had AHB counts ranging from 1.0 x $10^{7} \pm 0.6$ to $20 \times 10^{7} \pm 0.9$

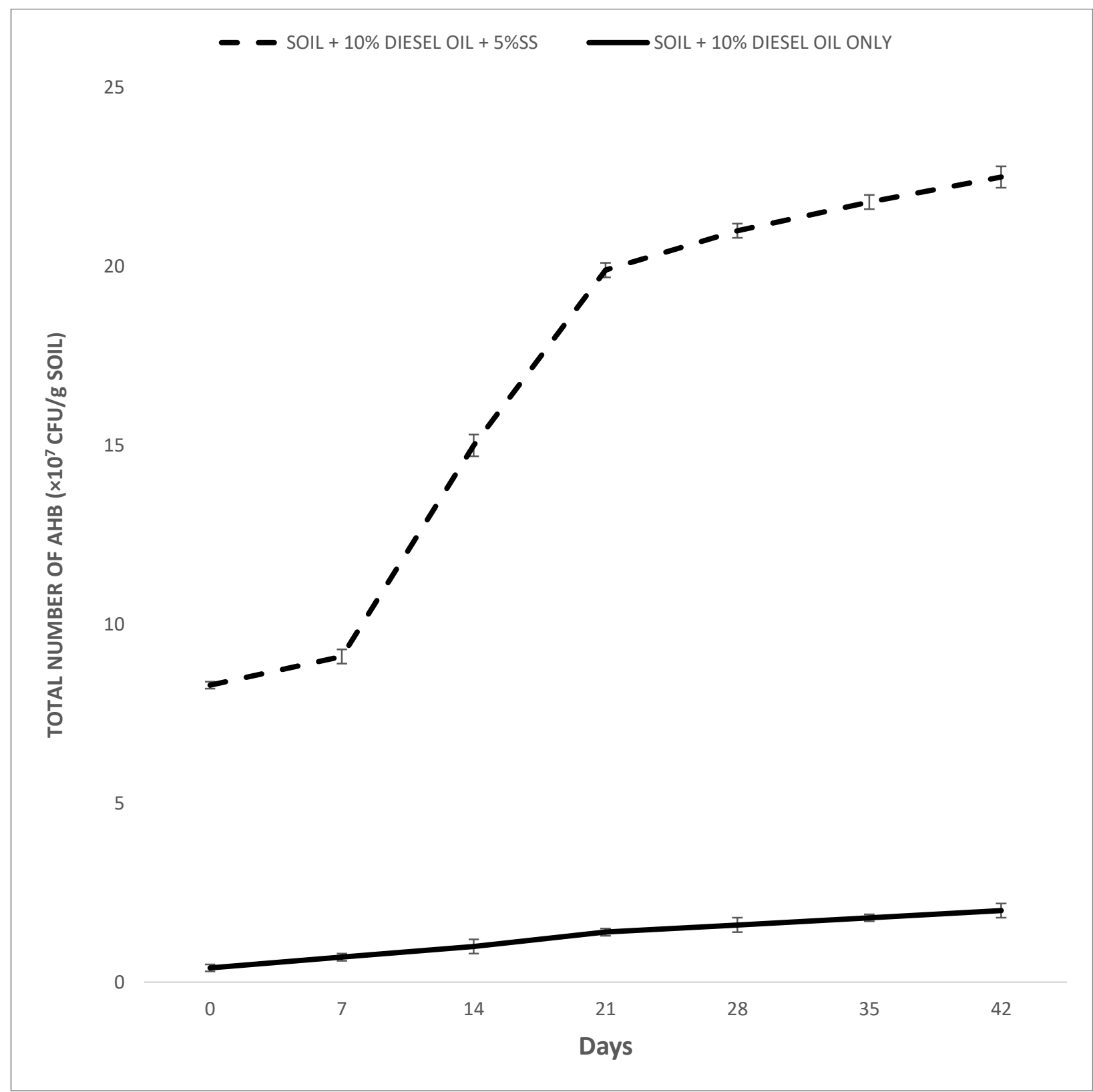

Fig.4: Aerobic heterotrophic bacterial (AHB) population in soil contaminated with $10 \%$ diesel oil and amended with 5\% SS 
Figure 5 shows the total number of aerobic heterotrophic bacteria in polluted soil amended with $10 \%$ SS and the control option. AHB in SS-amended option ranged from $9.2 \times 10^{7} \pm 0.28$ to $23.3 \times 10^{7} \pm 0.14 \mathrm{CFU} / \mathrm{g}$

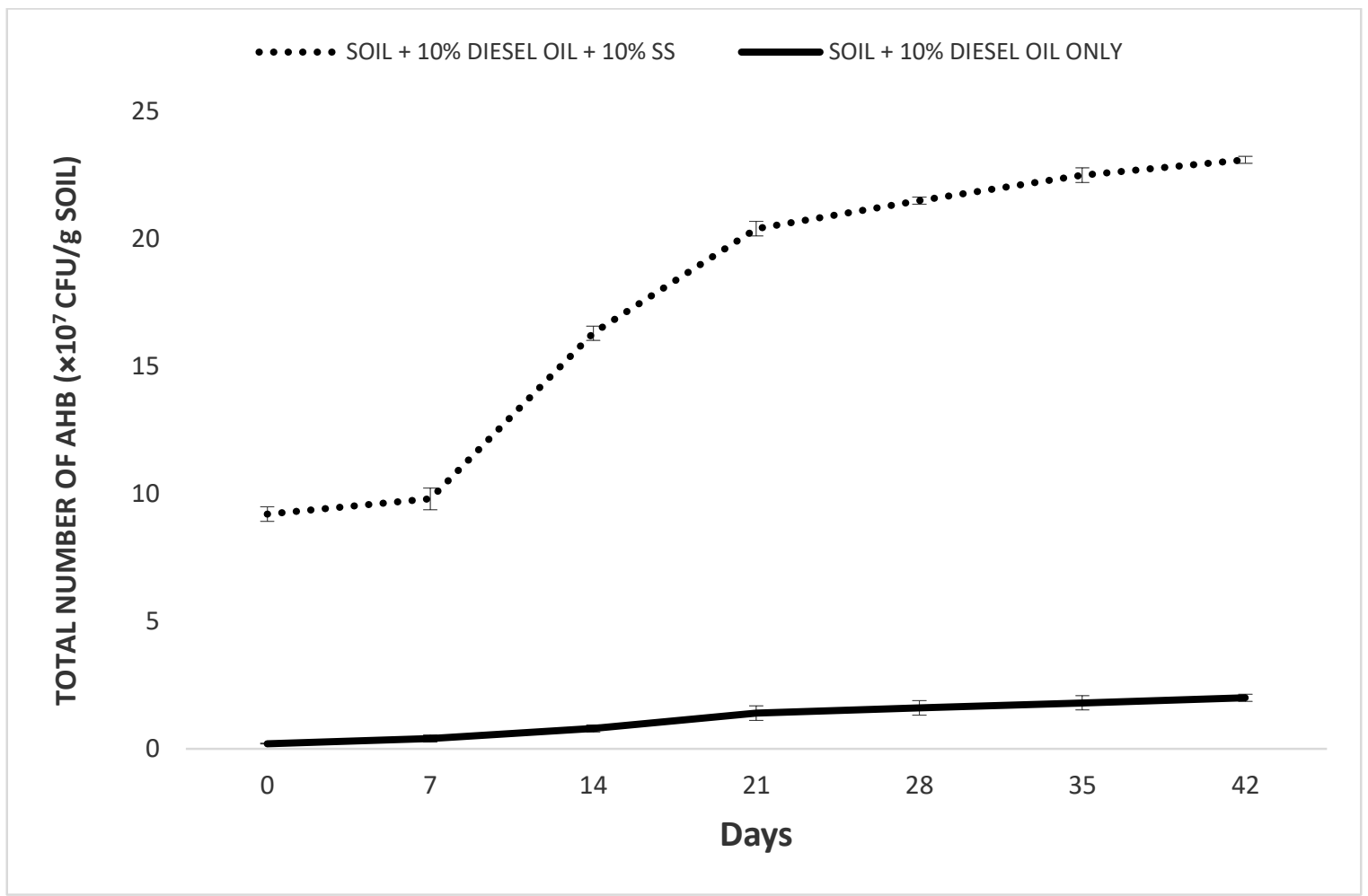

Fig.5: Aerobic heterotrophic bacterial (AHB) population in soil contaminated with $10 \%$ diesel oil and amended with $10 \%$ SS

AHB counts in the control option and polluted soil amended with $15 \%$ SS are presented in Figure 6. AHB counts ranged from $10.5 \times 10^{7} \pm 0.28$ to $24.0 \times 10^{7} \pm 0.78$ in the SS-amended option. 


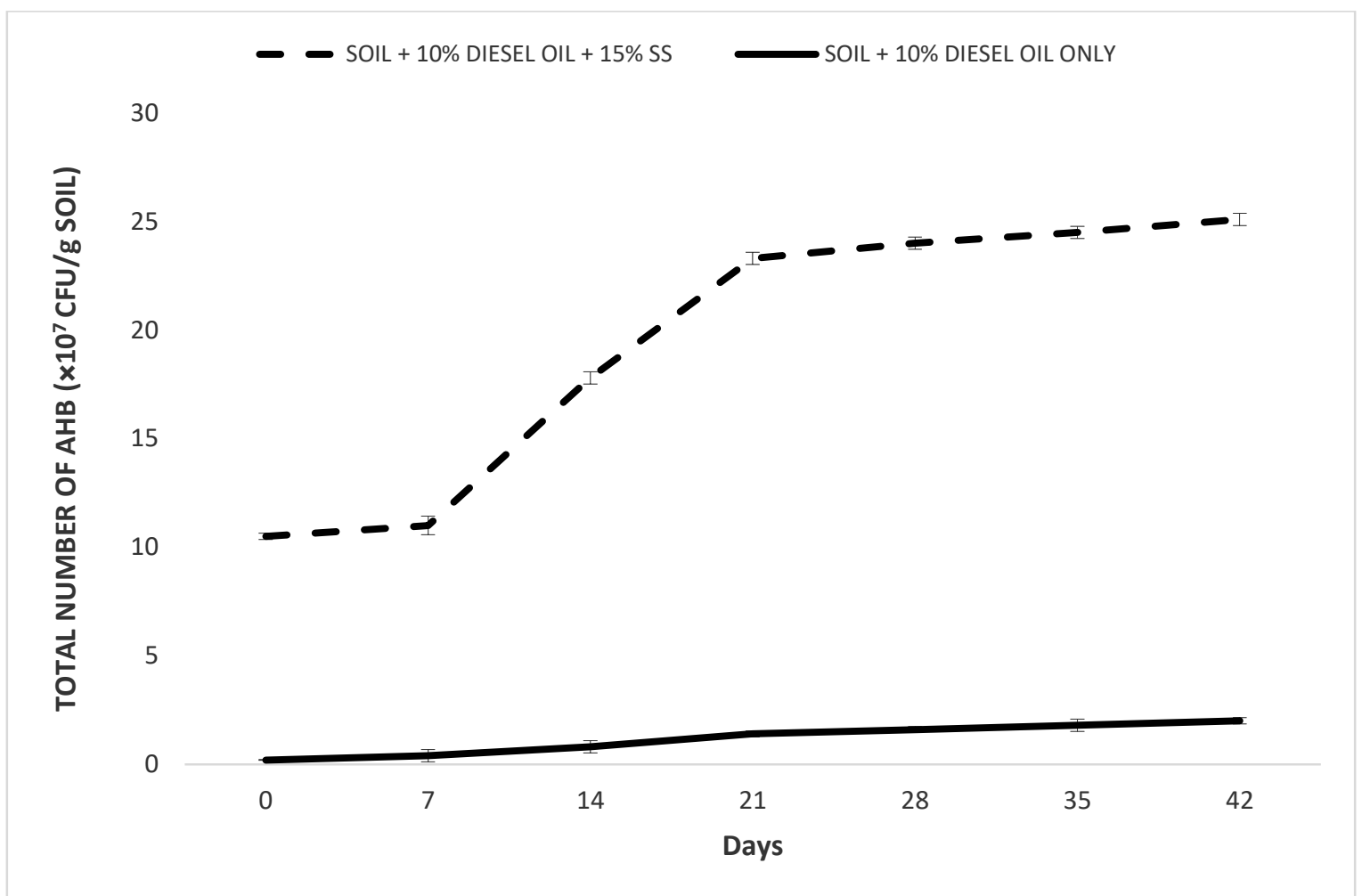

Fig.6: Aerobic heterotrophic bacterial $(A H B)$ population in soil contaminated with $10 \%$ diesel oil and amended with $15 \%$ SS Hydrocarbon-Utilising Bacterial (HUB) Counts

The profile of HUB count in control soil and oil-polluted soil amended with 5\% SS over a 42-day period is presented in Figure 7. HUB counts in the SS-amended option ranged from $4.8 \times 10^{6} \pm 0.71$ to $11.0 \times 10^{6} \pm 0.78$. The control option had a HUB count ranging from $0.8 \times 10^{6} \pm 0.13$ to $3.2 \times 10^{6} \pm 0.27$.

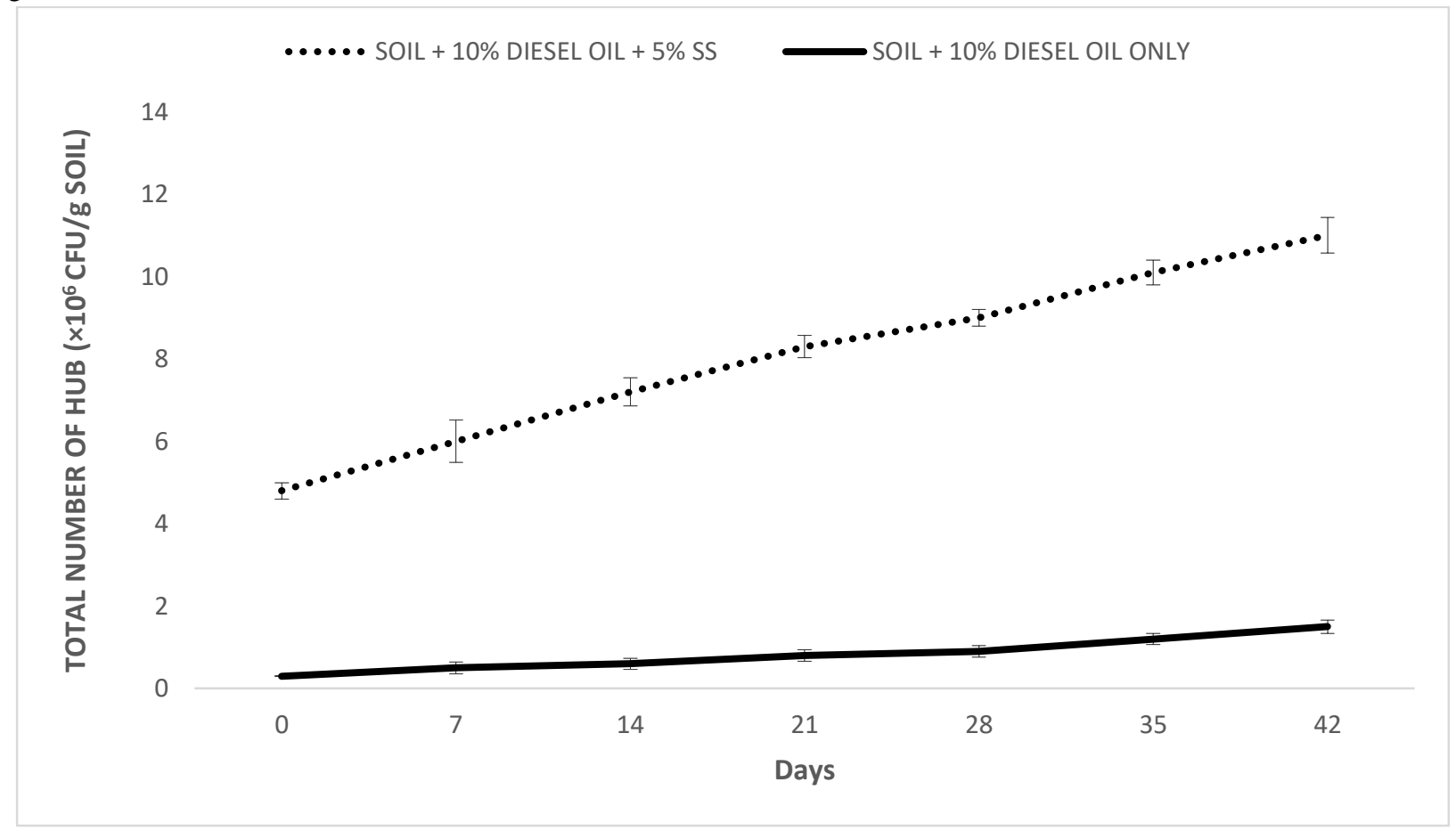

Fig.7: HUB counts in soil contaminated with $10 \%$ diesel oil and amended with $5 \%$ SS 
Figure 8 presents the HUB counts in the $10 \% \mathrm{SS}$-amendment option over a forty-two day period. HUB counts in the SS-amended option ranged from $5.0 \times 10^{6} \pm 0.48$ to $12.0 \times 10^{6} \pm 0.81$

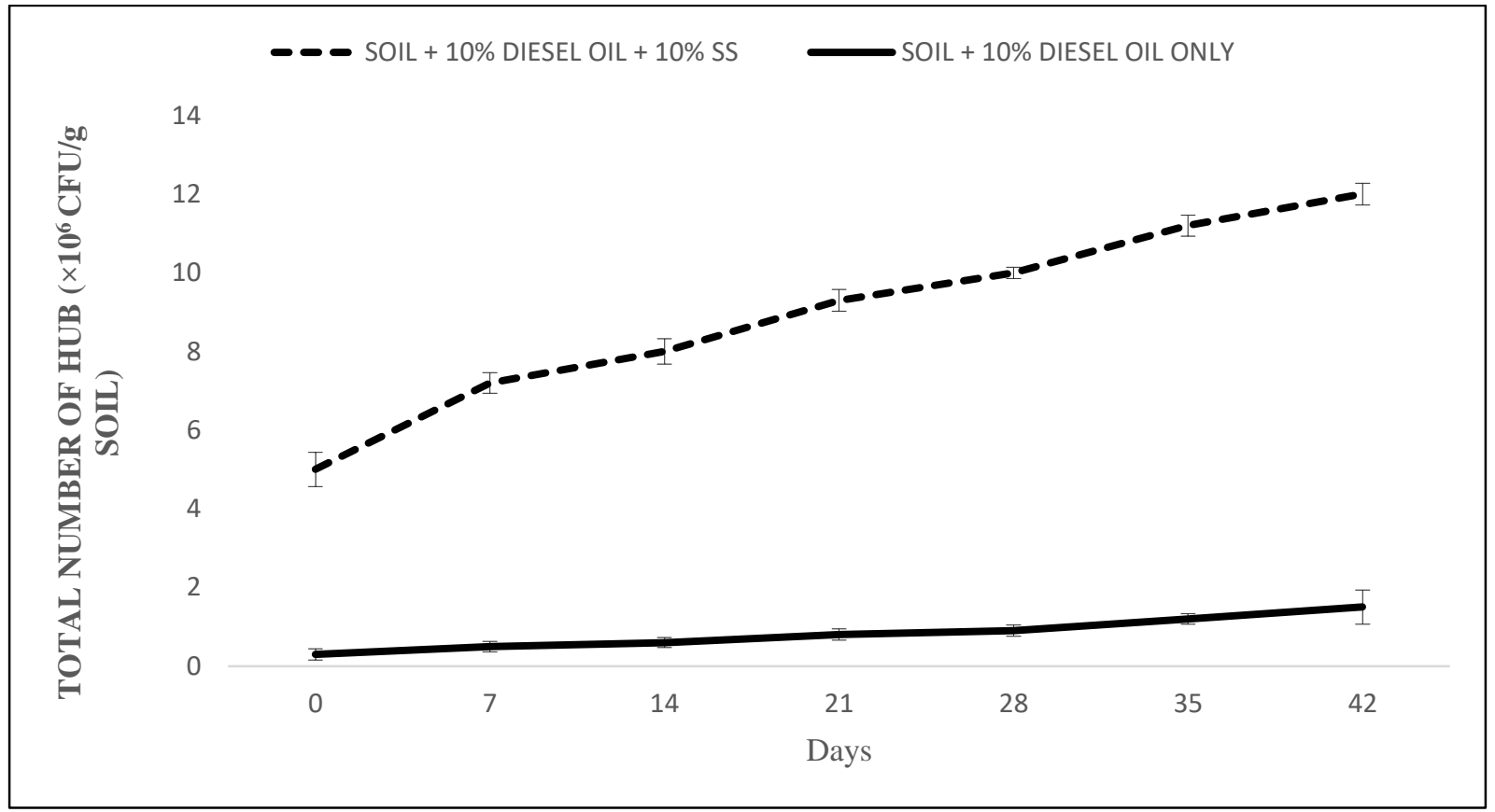

Fig.8: HUB counts in soil contaminated with $10 \%$ diesel oil and amended with $10 \%$ SS.

The hydrocarbon-utilising bacterial load in the control option and oil-polluted soil amended with $15 \%$ SS within 42 days are presented in Figure 9. AHB ranged from $6.2 \times 10^{6} \pm 0.31$ to $12.2 \times 10^{6} \pm 0.48$ in the SS-amended option. 


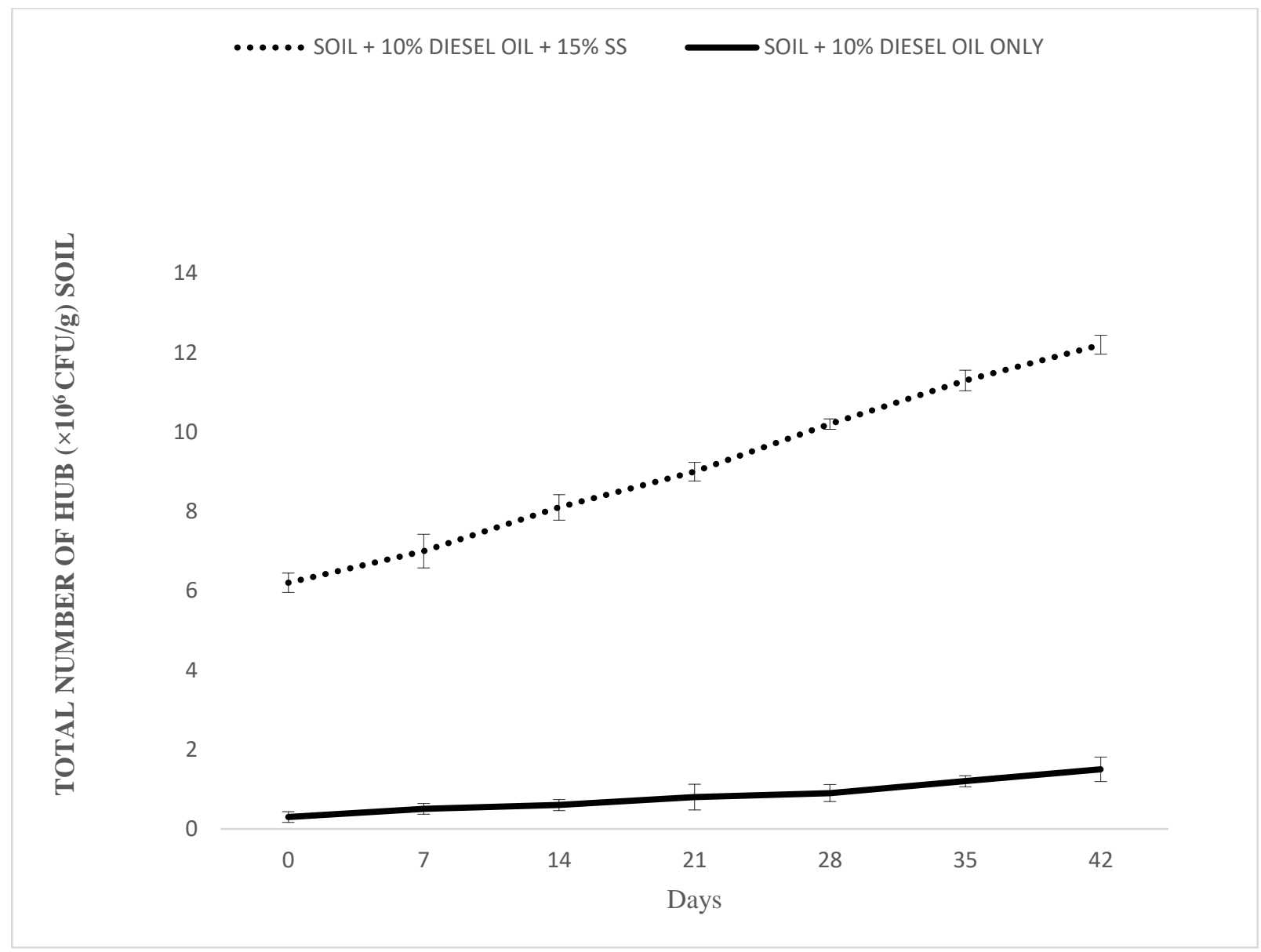

Fig.9: HUB counts in soil contaminated with 10\% diesel oil and amended with 15\% SS.

\section{Identities of Bacterial isolates}

The microscopic and biochemical characteristics of the isolated hydrocarbon-utilising bacteria are presented in Table 2. The HUBs are identified tentatively as Bacillus licheniformis, Pseudomonas putida, Corynebacterium sp., Micrococcus varians, Acinetobacter sp and Bacillus cereus

Table 2:Microscopic and Biochemical Characteristics of Bacterial Isolates

\begin{tabular}{|c|c|c|c|c|c|c|c|c|c|c|c|c|}
\hline ઇ & $\frac{\tilde{\Xi}}{\frac{\tilde{J}}{\pi}}$ & 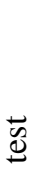 & 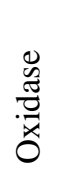 & $\stackrel{\varpi}{\Phi}$ & $\stackrel{\mathcal{N}}{\mathcal{I}}$ & 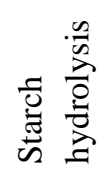 & $\begin{array}{l}\overrightarrow{0} \\
\frac{0}{\lambda} \\
\stackrel{\Xi}{\Sigma}\end{array}$ & 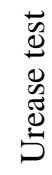 & 莺 & $\begin{array}{l}\stackrel{\Xi}{\Xi} \\
\stackrel{\Xi}{0} \\
\Xi\end{array}$ & 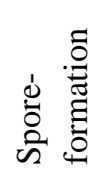 & 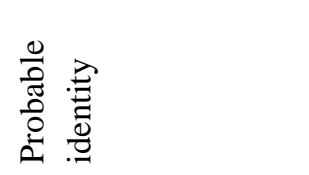 \\
\hline+ & + & & - & & - & + & + & - & - & + & + & Bacillus cereus \\
\hline+ & + & & + & & + & - & + & + & + & - & - & Micrococcus varians \\
\hline- & + & & - & & + & - & - & - & + & - & - & Acinetobacter $\mathrm{sp}$ \\
\hline- & + & & + & & - & + & - & + & + & + & - & Pseudomonas putida \\
\hline+ & + & & + & & - & - & - & - & - & - & - & Corynebacterium sp \\
\hline+ & - & & - & & - & + & - & - & - & + & + & $\begin{array}{l}\text { Bacillus } \\
\text { licheniformis }\end{array}$ \\
\hline
\end{tabular}




\section{Fungal Counts}

The active aerobic heterotrophic fungal counts in the 5\% amendment options and unamended control soil over a 42-day period is presented in Figure 10. Fungal counts in the SS-amended soil ranged from $3.8 \times 10^{5} \pm 0.11$ to $9.6 \times 10^{5} \pm 0.38$ while $0.3-2.0 \times 10^{5}$ $\pm 0.13-0.23$ is the range of fungal counts recorded in the unamended control soil.

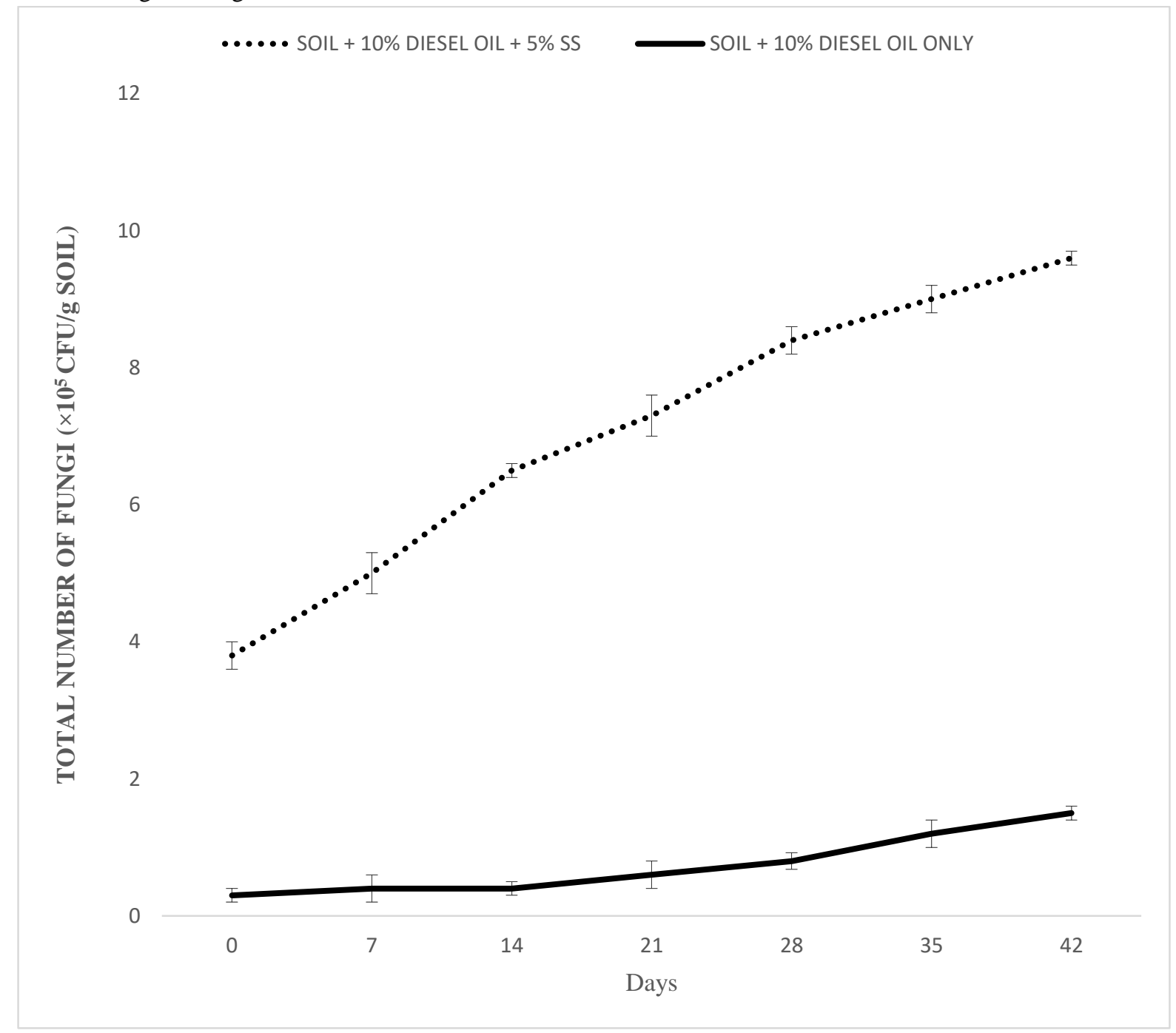

Fig.10: Fungal population in soil contaminated with $10 \%$ diesel oil and amended with $5 \%$ SS.

Fungal counts in the oil-polluted soil amended with 10\% SS and the control option over a 42-day period is presented in Figure 11. Fungal counts ranged from $4.9 \times 10^{5}$ to $10.9 \times 10^{5}$ in the SS-amended soil. 


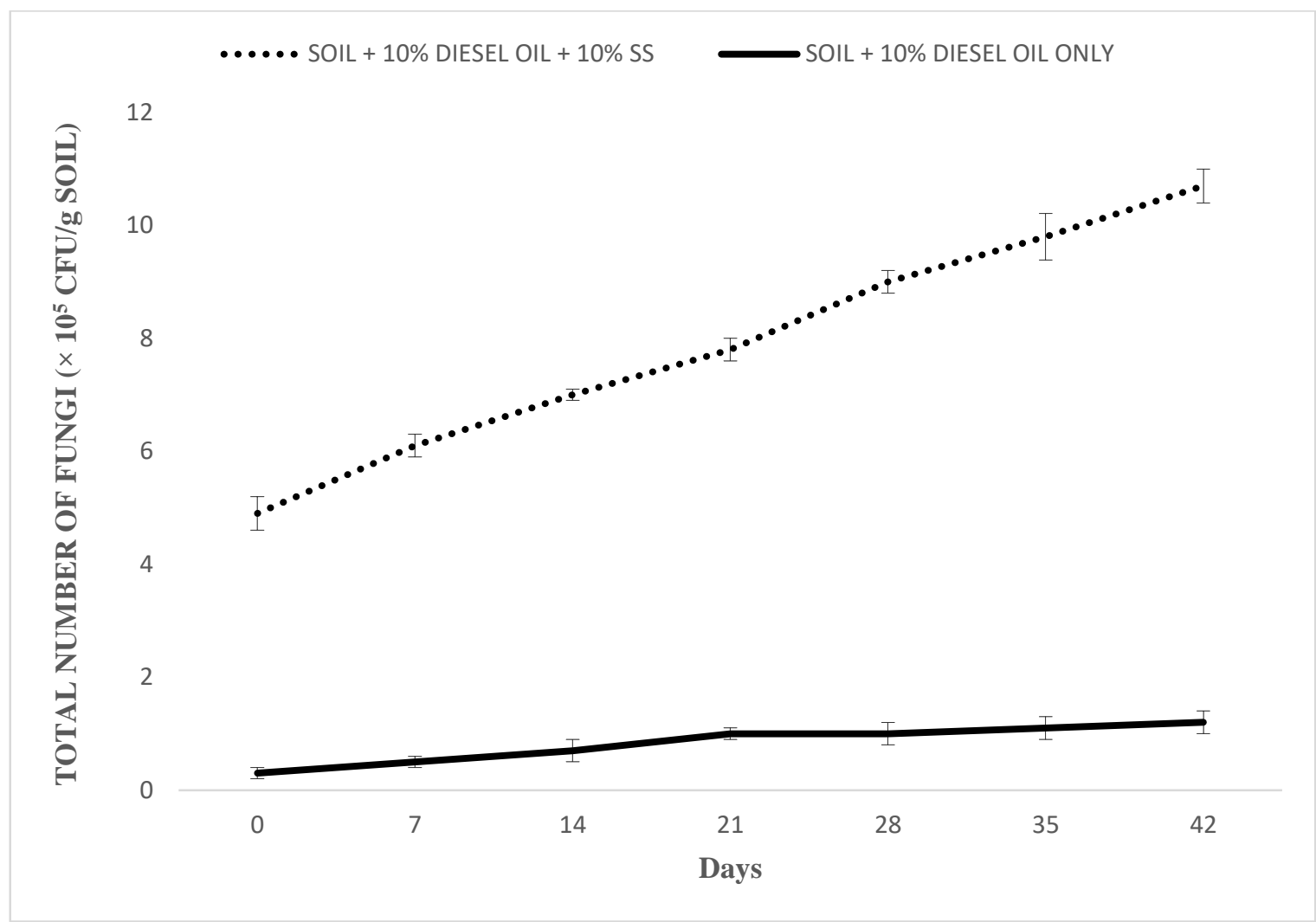

Fig.11: Fungal population in soil polluted with $10 \%$ diesel oil and amended with $10 \%$ SS.

Fungal load recorded in the 15\% SS-amendment options over a 42-day period is presented in Figure 12. It ranged from $6.0 \times 10^{5}$ \pm 0.22 to $11.6 \times 10^{5} \pm 0.39$

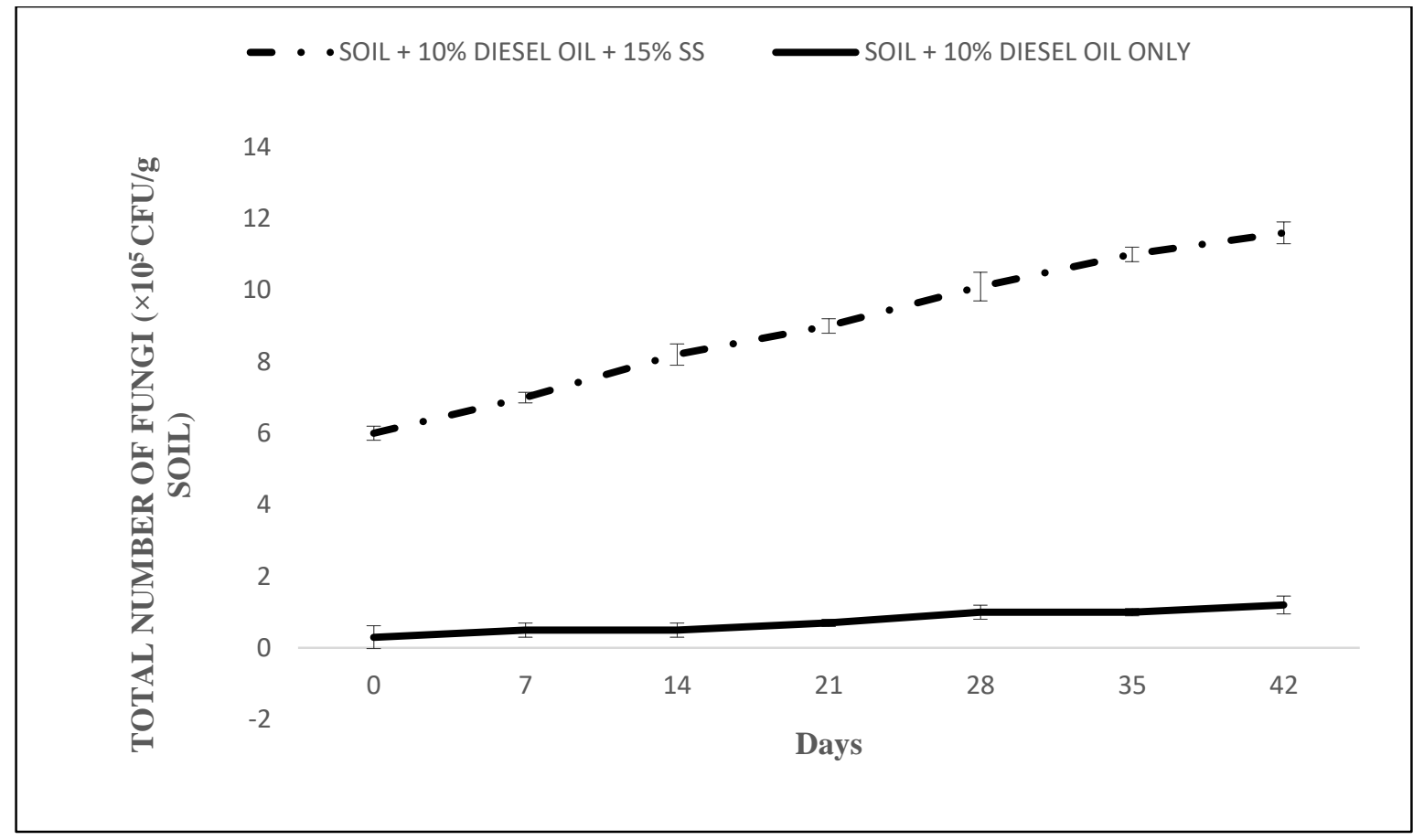

Fig.12: Fungal population in soil polluted with 10\% diesel oil and amended with 15\% organic wastes. 


\section{Identities of Fungal Isolates}

The cultural and microscopic characteristics of the isolated hydrocarbon-utilising fungi are presented in Table 3. Fungi isolated predominantly were identified tentatively as Aspergillus niger, Aspergillus flavus, Fusarium sp., Cladosporium sp. and Penicillium $\mathrm{sp}$

Table 3: Cultural and Microscopic Characteristics of Fungal Isolates

\begin{tabular}{|c|c|c|}
\hline Cultural characteristics & Microscopic Characteristics & Probable Identity \\
\hline $\begin{array}{l}\text { Dark brown, powdery, flat spread on the surface } \\
\text { of the solid medium with reverse }\end{array}$ & $\begin{array}{l}\text { septate and branched hyphae with } \\
\text { conidia in chains }\end{array}$ & Aspergillus niger \\
\hline $\begin{array}{l}\text { Yellow, powdery, flat spread on the surface of the } \\
\text { solid medium with colourless reverse }\end{array}$ & $\begin{array}{l}\text { Septate and branched hyphae with } \\
\text { conidia in chains }\end{array}$ & Aspergillus flavus \\
\hline $\begin{array}{l}\text { Grey colonies that were large with white border. } \\
\text { Colourless or white reverse }\end{array}$ & $\begin{array}{l}\text { Long conidiophores consisting of } \\
\text { broom-like conidia in chains }\end{array}$ & Penicillium $\mathrm{sp}$ \\
\hline $\begin{array}{l}\text { Whitish and cottony mycelium with pinkish } \\
\text { pigments at the centre. Brown reverse side }\end{array}$ & $\begin{array}{l}\text { segmented canoe-shaped spores } \\
\text { and branched conidiophores }\end{array}$ & Fusarium spp \\
\hline 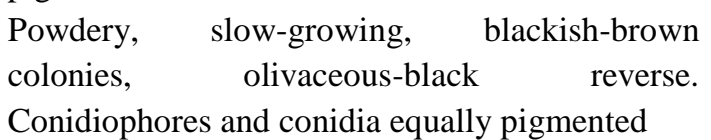 & $\begin{array}{l}\text { Branched and shield-shaped } \\
\text { conidia in chains }\end{array}$ & Cladosporium sp \\
\hline
\end{tabular}

\section{Seed Germination Toxicity}

Seed germination parametres employed in this study are presented in Table 4. SG (\%) ranged from 66.7 to 83.3 across all amendment levels in the SS-amendment option while negative and positive control soils had SG (\%) of 16.7 and 100 , respectively. LR (\%) ranged from 58.5 to 87.7 across all amendment levels in the amendment option while 16.9 and 100 were recorded in the negative and positive control, respectively. Furthermore, GI ranged from 39.0 to 73.1 across all amendment options. Negative and positive control had GI of 2.8 and 100

Table 4: Seed Germination Parametres

\begin{tabular}{llllll}
\hline Soil preparations & SG & LR $(\mathrm{cm})$ & SG $(\%)$ & LR $(\%)$ & GI \\
\hline 5\% SS & $4.0 \pm 0.14$ & $3.8 \pm 0.43$ & 66.7 & 58.5 & 39.0 \\
$10 \%$ SS & $5.0 \pm 0.43$ & $4.5 \pm 0.15$ & 83.3 & 69.2 & 57.6 \\
$15 \%$ SS & $5.0 \pm 0.26$ & $5.7 \pm 0.02$ & 83.3 & 87.7 & 73.1 \\
Negative control & $1.0 \pm 0.00$ & $1.1 \pm 0.01$ & 16.7 & 16.9 & 2.8 \\
Positive control & $6.0 \pm 0.01$ & $6.5 \pm 0.00$ & 100 & 100 & 100 \\
\hline
\end{tabular}

Key: number of seeds that germinated, $\mathrm{LR}=$ root length, $\mathrm{GI}=$ germination index

\section{DISCUSSION}

Several studies on hydrocarbon remediation have shown that bioremediation employing the activities of microbes alone proved inadequate $[20,11,12]$. It was argued [21] that while hydrocarbons are excellent sources of carbon and energy to microbes, they are incomplete foods in that they do not contain significant concentrations of other nutrients such as nitrogen and phosphorus required for microbial growth. The dearth of nutrients in soils polluted with hydrocarbons poses a challenge to bioremediation; nevertheless, nutrient addition generally favours soil hydrocarbon-utilising bacteria and fungi, ultimately resulting in enhanced bioremediation of hydrocarbon-polluted environments [8]. By adding organic wastes, the C:N and C:P ratios of the soil becomes closer to the bacterial requirements of the same.

It was reported [3] that bioremediation of diesel fuel depended on phosphorus ability. However, some nutrient sources might supply enough phosphorus to restore the microbial C:P relationship but become unavailable due to their low solubility [22]. Pivotal therefore, is the knowledge of nutrient bioavailability to planning an efficient bioremediation protocol.

The percentage nitrogen content of the soil used in this study was comparably low (Table 1). Hydrocarbon degraders need more nitrogen and phosphorus than is normally present in soils to convert excess carbon present in hydrocarbon 
pollutants to biomass [21]. In a similar vein, it was stated [23] that although microorganisms are present in contaminated soil, they cannot necessarily be present at levels required for bioremediation of the site, hence the need for their growth and activities to be stimulated. The soil used in this study had high C:N ratio of 59:1 (Table 1). Furthermore, pollution of the experimental soil with $10 \% \mathrm{v} / \mathrm{w}$ diesel oil introduced more carbon to the soil, thereby increasing its $\mathrm{C}: \mathrm{N}$ ratio. As a general rule of thumb, materials with a $\mathrm{C}: \mathrm{N}$ ratio greater than 25:1 stimulate immobilization [24]. Carbon is the most basic form of nutrient required for living organism. In addition to this, bacteria also need macronutrients such as nitrogen and phosphorus to ensure effective degradation of the oil. However, the ratio of carbon to essential nutrients such as nitrogen and phosphorus is critical to the realization of an effective bioremediation. As organisms convert excess carbon present in hydrocarbon spills onto biomass, they require corresponding proportions of these essential nutrients. The optimum nutrient balance required for hydrocarbon remediation is $\mathrm{C}: \mathrm{N}: \mathrm{P}$ equals 100:10:1 [25,23]. Higher polycyclic aromatic hydrocarbon degradation was recorded in soil amendment with $\mathrm{C}: \mathrm{N}$ ratio of 10:1 than those with C:N ratio of $25: 1$ and 40:1, respectively [26]. In the present study, therefore, the addition of sewage sludge rich in organic nitrogen obviously balanced the $\mathrm{C}: \mathrm{N}$ ratio of the soil at a level that enhanced growth and activities of microbes. This enhancement ultimately favoured degradation of diesel oil pollutant.

The result of the extraction efficiency experiment clearly indicated that $n$-hexane was the best choice in extracting diesel oil under the conditions employed in this study. This is due to the fact that the highest amount of diesel oil was extracted with n-hexane among other solvents such as dichloromethane and diethylether used in this study.

Percentage oil loss (bioremediation) increased appreciably from the first week to the sixth week in both the amendment and control options (Figures 1-3). However, as was observed throughout the study period, oil loss increased with increasing concentration of sewage sludge. Highest oil loss was noted in the polluted soil amended with 15\% SS (Figure 3). The observation of highest oil loss in the SS-amended option was probably due to its relatively higher content of organic nitrogen (Table 1). Positive effects of nitrogen amendment has been demonstrated [27]. It has been reported that when oil is applied at rates of $0.5-10 \%$ based on the weight, extensive bioremediation of the oil components occurs within the first three months [12]. Oil loss in the control option also increased notably from $19.23 \%$ to $32.22 \%$ at the end of 42 days. A similar study on diesel oil remediation using soy cake, potato skin and tea leaf amendment recorded $35 \%$ oil loss in the control option [28]. A 42-day study on crude oil remediation using only goat manure as amendment recorded $8.15 \%$ oil loss for the control microcosm at the end of the study [16]. Part of the oil loss in the control option could be due to some factors such as natural bio attenuation by the indigenous hydrocarbondegrading flora, photo degradation, volatilization, sorption, dilution and dispersion. Similar observation was noted [22]. Greater oil loss was recorded in the amendment options than the control option. Similar trend have been widely documented [10, 12, 22].

Even though the application of bio stimulation strategy in bioremediation has gained wide acceptance, reports on the bio stimulation potentials of organic amendments have been widely divergent in literature. While some researchers documented a direct (linear) relationship between hydrocarbon remediation and impact of organic wastes $[8,29]$, another proved otherwise by reporting that natural attenuation was more successful than bio stimulation in Hong Kong soil [30]. It was also found that nutrient supplementation had no significant effect on the remediation of polluted soils [31]. However, it was asserted that different soils have varying inherent microbial potentials to degrade hydrocarbons [32]. Ways to activate these potentials must bring into account that most degradation potentials are widely distributed among microorganisms and indigenous microbes are always present in small numbers.

The growth and activities of heterotrophic bacteria and fungi are a biological indicator of the impact of organic wastes. In the present study, AHB counts increased progressively throughout the study in the amendment and control options (Figures 4-6). However, AHB counts were higher in the amended option (at all amendment levels) than the control option. It was also observed that highest counts were recorded at $15 \%$ amendment level. This could be as a result of enhanced nutrient level in the highest level of amendment. Earlier researchers noted similar observation [11, 33]. AHB counts of $8.0 \times 10^{6}-30.0 \times 10^{6}$ was recorded in the amended option in a study on diesel oil remediation using cowpea chaff [33]. In a similar study, AHB counts ranging from 3.4 x $10^{3}-2.9 \times 10^{5} \mathrm{CFU} / \mathrm{g}$ were recorded in the control soil [16]. Similarly, HUB counts increased markedly from $4.8 \mathrm{x}$ $10^{6} \pm 0.9$ to $12.3 \times 10^{6} \pm 0.75 \mathrm{CFU} / \mathrm{g}$ soil throughout the study period (Figures 7-9) and higher HUB counts were recorded in the amended option than the control. Similar observation had been documented [34]. Furthermore, as was noted in the 
population count profile of AHB and HUB, fungal population increased progressively throughout the study period (Figures 10-12) and was highest at the highest amendment level (15\%) (Figure 12). The observation of greater AHB, HUB and fungi in the amended option than the control option might also be attributed to the fact that sewage sludge harbor great diversities of microbes with inherent hydrocarbon-degrading potentials. Technically speaking therefore, addition of organic wastes such as sewage sludge can be regarded as 'uncontrolled bioaugmentation'. It was noted in this study that AHB counts were higher in number than their hydrocarbon-utilising counterparts. Similar trend was noted [20]. It stands to reason therefore that HUB are a significant proportion of heterotrophic bacteria that evolved probably as a result of incessant soil pollution with hydrocarbons. The HUB isolated in this study were identified tentatively as Bacillus licheniformis, Pseudomonas putida, Corynebacterium sp., Micrococcus varians, Acinetobacter sp and Bacillus cereus (Table 2). These bacteria have been widely reported [11, 20,22] as having hydrocarbonutilisation attributes. Also, fungi isolated in the present study were identified tentatively as Aspergillus niger, Aspergillus flavus, Fusarium sp., Cladosporium sp. and Penicillium sp. (Table 3) These have also been reported by several researchers [29, 35] as being implicated in hydrocarbon degradation. It was observed that the hydrocarbon-degrading bacterial population in the amended option were higher than their fungal counterparts. It was argued [36] that although it is widely accepted that bacteria and fungi are primary mediators in hydrocarbon remediation, bacteria have been found to be more versatile than fungi and therefore may play a greater role during biodegradation of hydrocarbons. Generally, bioremediation levels and microbial counts may vary among similar studies. This may be due to the assertion that the fate and effect of oil depends on the type of oil and extent of pollution, properties of oil as modified overtime by physical and chemical processes, the organisms and habitats exposed and the nature of the exposure [21].

Seed germination toxicity test has been demonstrated as a good parameter of assessing the efficacy of bioremediation on contaminated soils [18]. The highest germination index was recorded in the SS-amended option at $15 \%$ amendment level (Table 4). GI recorded in the present study followed the same pattern as bioremediation results and microbial counts. All the seeds germinated in the positive control soil while one seed germinated in the negative control soil (Table 4). This could be attributed to absence of oil pollution in the positive control soil and oil pollution in the negative control soil. Oil pollution has been identified by different researchers [37, 2] as having adverse effects on plant development parametres. Growth of all seeds of Moringa olifera planted in the positive control option was recorded [38]. Positive control option also allowed $99.6 \%$ germination [37]. Phaseolus vulgaris normally germinates within 8-10 days but the germination was delayed to 19-21 days owing to slightly heavy pollution simulated in this study $(10 \%)$ which had not been fully remediated (58.33\%) as at the end of the 42-day study period. There was a significant difference in bioremediation level and microbial counts $(\mathrm{P} \leq 0.05)$ between SS-amended soil and control even at $5 \%$ level.

\section{CONCLUSION}

This study showed that bioremediation employing the impact of organic amendments to soil polluted with diesel oil enhanced the activities of the remediating microflora by improving nutrient supply. Sewage sludge alone or in combination with other wastes can therefore offer a good alternative to the rather expensive physical and chemical methods of hydrocarbon remediation.

\section{ACKNOWLEDGEMENT}

The authors' appreciation goes to Dr. V.N. Chigor of the Department of Microbiology, University of Nigeria for the use of his laboratory facilities.

\section{REFERENCES}

[1] APHA (2008) American Public Health Association, Standard Methods for the Examination of Water and Wastewater, $21^{\text {st }}$ Edition, Washington DC.

[2] Ayandele, A.A. (2018). Biotreatment of soil contaminated with spent engine oil by locally isolated microorganisms. Advances in Environmental Microbiology. 12(11):22-28

[3] Ogbo, E.M. (2009). Effects of diesel fuel contamination on seed germination of four crop plants-Arachis hypogaea, Vigna unguiculata,Sorghum bicolor, and Zea mays. African Journal of Biotechnology. 8:(2):250-253

[4] Agarry, S.E. and Latinwo, G.K. (2015). Biodegradation of diesel oil in soil and its enhancement by application of bioventing and amendment with brewery waste effluents as biostimulation bioaugmentation agents. Journal of Ecological Engineering.16(2):82-91

[5] Brady, R.N.(2001). Diesel Fuel. In:Macmillan Encyclopedia of Energy. Vol. 1. Ed. John Zumerchik. Macmillan Reference USA. New York: 336-342

[6] Riffaldi, R., Levi-Minzi, R., Cardelli, R., Palumbo, S., Saviozzi, A.(2006). Soil biological activities in monitoring the bioremediation of diesel oil-contaminated soil. Water, Air, and Soil Pollution, 170, 3-15. 
[7] Eramo, A. (2009).Bioremediation of diesel contaminated soil using spent mushroom compost. A thesis in Environmental Engineering. The Pennsylvania State University. Pp 1-3

[8] Awofeso, N.(2011). Generator diesel exhaust: a major hazard to health and the environment in Nigeria. American Journal of Respiratory and Critical Care Medicine, 183(10), pp. 1437.

[9] Abioye, P., Abdul Aziz, A., Agamuthu, P. (2009a). Enhanced biodegradation of used engine oil in soil amended with organic wastes. Water, Air, and Soil Pollution, 209(1): 173179.

[10] Azubuike, C.C., Chikere, C.B. and Okpokwasili, G.C. World Journal of Microbiology and Biotechnology (2016) 32: $180 . \quad$ https://doi.org/10.1007/s11274-016-2137-x. Retrieved 05/12/19

[11] Adesodun J.K., Mbagwu J.S.C. (2008), Biodegradation of waste-lubricating petroleum oil in a tropical alfisol as mediated by animal droppings, Bioresource Technology, 99(13), 5659-5665.

[12] Onuoha, S.C. (2013).stimulated biodegradation of spent lubricating motor oil in soil amended with animal droppings. Journal of Natural Sciences Research,3 (12), 106-116

[13] APHA (2008) American Public Health Association, Standard Methods for the Examination of Water and Wastewater, $21^{\text {st }}$ Edition, Washington DC.

[14] Agamuthu, P., Dadrasnia, A. (2013). Potential of biowastes to remediate diesel fuel contaminated soil, Global NEST Journal, 15(4), 474-484.

[15] Aremu, M. O., Araromi, D. O. and Gbolahan, O.O. (2015).Regeneration of used lubricating engine oil by solvent extraction process. International Journal of Energy and Environmental Research, 3(1):1-12

[16] Odokuma, L.O. \&Ibor, M.N. (2002). Nitrogen fixing bacteria enhanced bioremediation of crude oil polluted soil. Global Journal of Pure and Applied Science, 8(4),455-468.

[17] Nwogu, T.P., Azubuike,C.C. and Ogugbue, C.J. (2015). Enhanced bioremediation of soil artificially contaminated with petroleum hydrocarbons after amendment with Capra aegagrus hircus (goat) manure. Biotechnology research international. 2015:22-29

[18] Tsuneo, W. (2002).Pictorial atlas of soil and seed fungi; Morphologies of cultured fungi and key to species.Second edition, CRC press, Boca Raton, London, Newyork. Washington D.C. Pp 1120-1125

[19] Jaqueline, M.C., Paulo, R.M., Renato, N.M., Ivo, S.T., Natalia, M.G.S. and Ederio, D.B. (2013). Toxicity assessment of contaminated soil using seeds as bioindicators. Journal of Applied Biotechnology. 1(1):34-40

[20] Millioni, V.S., Servulo, E.L.C., Sobral, L.G.S. and De Carvalho, D.D. (2009). Bioremediation of crude oil-bearing soil: evaluating the effect of Rhamnolipid addition to soil toxicity and to crude oil biodegradation efficiency. Global NEST journal.11(2):181-188
[21] Akpe, A. R., Ekundayo, A. O., Aigere, S.P. and Okwu, G. I.(2015). Bacterial degradation of petroleum hydrocarbons in crude oil polluted soil amended with cassava peels. American Journal of Research Communication, 3(7), 99- 118

[22] Ubalua, A.O. (2011). Bioremediation strategies for oilpolluted marine ecosystems.Australian Journal of Agricultural Engineering. 2(6), 160-168.

[23] Agarry, E.S. and Jimoda, L. (2013). Application of carbonnitrogen supplementation from plant and animal sources in insitu soil bioremediation of diesel oil: experimental analysis and kinetic modelling. Journal of Environment and Earth Science. 3 (7): 51-62

[24] Thapa, B., Ajay, K.C.K. and Ghimere, A. (2012). A review on bioremediation of petroleum hydrocarbon contaminants in soil. Kathmandu University Journal of Science, Engineering and Technology. 8(1):164-170

[25] Robertson, G.P. and Groffman, P.M. (2007).Nitrogen transformations. In: Eldor, A. Paul (ed.) soil microbiology and biochemistry.3rd edition. Pp 341-347. Elsevier Incorporated. Oxford, United Kingdom.

[26] Okoh, I.O. (2006). Biodegradation alternative in the cleanup of petroleum hydrocarbon pollutants. Biotechnology and Molecular Biology Review. 1(2):38-50

[27] Teng, Y., Luo, Y., Ping,L., Zou, D, Li, Z. and Christie, P. (2010). Effects of soil amendment with different carbon sources and other factors on the bioremediation of an aged PAH-contaminated soil. Biodegradation. 21:167-178

[28] Margesin, R., Hammerle, M. and Tscherko, D.(2007). Microbial activity and community composition during bioremediation of diesel oil-contaminated soil: Effects of hydrocarbon concentration, fertilizers and incubation time. Microbial Ecology, 58(2), 259-269

[29] Dadrasnia, A. \&Agamuthu, P. (2010).Enhanced degradation of diesel-contaminated soil using organic wastes.Malaysian Journal of Science.29, 225-230.

[30] Stephen, E. and Temola, O.E. (2014). Enhanced biodegradation of spent lubricating oil contaminated soil using poultry litter. British Biotechnology Journal, 4(8), 868876

[31] Bento, F.M., Camargo, F.A.O., Okeke, B.C. and Frankenberger, W.T. (2005). Comparative bioremediation of soils contaminated with diesel oil by natural attenuation, biostimulation and bioaugmentation. Bioresource Technology. 96(9): 1049-1055

[32] Seklemova, E., Pavlora, A. and Koracheva, K.(2001). Biostimulation-based bioremediation of diesel fuel field demonstration. Biology. 12:311-316

[33] Padayachee, D. and Lin, J. (2011). The effect of fertilizer amendment on diesel biodegradation in contaminated soils. African Journal of Microbiology Research. 5(14):1729-1739

[34] Stephen, E., Job, O.S. and Abioye, O.P. (2013). Study on biodegradation of diesel-contaminated soil amended with 
cowpea chaff. Journal of Science and Multidisciplinary Research. 2(1)14-18

[35] Ibiene, A.A., Orji, F.A., Ezidi, C.O. and Ngwobia, C.L. (2011). Bioremediation of hydrocarbon-contaminated soil in the Niger Delta using spent mushroom compost and organic wastes. Nigerian Journal of Agriculture, Food and Environment.7(3):1-7

[36] Chaudhry, S., Luhack, J., Sharma, V. and Sharma, C. (2012). Assessment of diesel-degrading potential of fungal isolates from sludge soil of petroleum refinery, Haryana.Research journal of Microbiology and Biotechnology. 28:1-9

[37] Chikere, C.B., Okpokwasili, G.C. and Chikere, B.O. (2011). Monitoring of hydrocarbon remediation in soil. Biotechnology.1(3):117-138

[38] Okechalu, O.B., Oke, F.M., Egbere, O.J. and Okechalu, J.N. (2014). Effects of biostimulation with organic amendment on the growth and yield of maize (Zea mays) in diesel oilpolluted soil. Journal of Pharmacy And Biological Sciences. 8:40-44

[39] Agbogidi, O.M. and Ilondu, E.M. (2013). Effects of spent engine oil on the germination and seedling growth of Moringa olifera (Lam.). Scholarly Journal of Agricultural Science. 3(6):293-243 